\title{
Unequal Education in Preschool
}

\author{
Gender at Play
}

\author{
Jessica Prioletta
}

$\cos$

\begin{abstract}
In this article, I explore how the beliefs of preschool teachers that equality is the norm in their classrooms shape play periods in ways that may work to disadvantage girls. I argue that equality discourses mask the gender power children must negotiate in their play and that this leaves girls with fewer choices when they are accessing the play environment. With research grounded in fieldwork carried out in four public schools in a Canadian metropolis, I illustrate how liberal notions of equality reinforced the traditional gender binary in children's play. Moreover, drawing on the work of Jane Roland Martin, I show that liberal understandings of equality work to sustain a male-centered education for all students in preschool. To explore ways to attend to such gender inequalities, I turn to Nel Noddings's concept of an ethics of care and point to the need to challenge the gender binary in early learning.
\end{abstract}

Keywords: early childhood education, equality discourses, ethics of care, gender inequality, male-centered education, teacher perspectives

In 2001, in an effort to reform preschool and elementary education, the Québec Ministry of Education implemented the Québec Education Program (QEP), which mandates play in early learning. In 2015, I carried out a study to investigate how this mandate has influenced teacher practice in the classroom, specifically as it relates to gender. ${ }^{1}$ My experience of teaching preschool in Québec and my curiosity about a statement in the QEP that claims, "Through play, sharing and experimentation, children also discover various trades and occupations" (Ministère de l'Éducation du Loisir et du Sport 2001: 45) inspired me to carry out this study. Noticing in my classrooms that girls and boys often played separately, with girls tending to play with kitchen sets and dolls and boys with blocks, trucks, and cars (see also Cherney and Dempsey 2010; Nelson 2011) called into question whether or not girls and boys are receiving an equal education in the preschool classroom and discovering the same "trades and occupations" during play.

In this article, I draw attention to the common perception among the preschool teachers that equality prevailed in their classrooms. An analysis 
of the data collected in four preschool classrooms revealed that a liberal understanding of equality informed teachers' perceptions of and practices around play and gender. I argue that such an understanding of equality silences the unequal gender power relations that permeate children's play and the ways in which they limit girls' access to the different spaces of the classroom play environment. The data shows that liberal notions of equality worked to perpetuate Jean-Jacques Rousseau's and Plato's historical philosophies of education and gender. Drawing on Jane Roland Martin's (1982, $1985,1994)$ concept of the productive and reproductive processes of society, I illustrate that the enduring influence such historical philosophies have had on conceptions of equality in education promote a male-centered education for all students. To conclude, I discuss how Nel Noddings's (2005) concept of an ethics of care in education may help to address gender inequality in preschool. I suggest that an ethics of care can work to challenge the gender binary upon which gender inequalities rely. While several play centers were made available in the classrooms I visited, including the blocks and the kitchen centers along with the sensory, the math, and the drawing/writing centers, I focus on the blocks and the kitchen centers since all four classrooms consistently had both these centers available during play throughout my visits.

\section{Collecting the Data}

Over the course of three months, I visited the classrooms of Sara, Hannah, Megan, and Laurie, ${ }^{2}$ which were located in schools in a large Canadian urban center. I used three data collection methods as part of a qualitative and feminist methodology. Feminist research makes use of semi-structured interviews since they facilitate the participants' active involvement in the construction of data and knowledge so, following Brooke Ackerly and Jacqui True (2010), I carried out a semi-structured interview with each teacher during the first and third visits to her classroom. For the second visit, the teachers were invited to take photographs of their students during play in response to the prompt: A typical play instance in my classroom. Each teacher then participated in a photo elicitation interview. During all three visits to each classroom, I carried out participant observation during the children's play periods. This allowed me to record more intimate accounts of the four-year-old children's play. As Liz Jones and Bridget Somekh (2005) point out, being embedded in the context of each classroom allowed me to 
gain greater insights and understandings of the teachers' and students' interactions during play. Finally, at the third visit, I carried out member checking as outlined by Keith Punch (2009) with each teacher to discuss the themes that had emerged from the first and second visits across the four classrooms. These data collection methods were used to minimize my influence and encourage the participants' active involvement in shaping the data.

To analyze the data, I coded full transcripts of the teacher interviews and my fieldnotes from my participant observation during children's play periods. Through this process, three themes emerged. The first theme centered on pedagogy and reflected the notion that play is a good and necessary pedagogical practice in early childhood education. The second theme concerned perceptions of young children and reflected the notion that children are developing, autonomous subjects who are too young to know about gender. The third theme involved the challenges teachers face in addressing gender when they use play in their classrooms. Further analysis of these three themes revealed an underlying assumption that children are treated equally in the preschool classroom. In other words, play, perceived as the appropriate child-centered practice, allows for free choice that ensures that all children, perceived as autonomous subjects, could access and make use of the play environment equally. When equality did not prevail, the challenge to close the gender gap in children's play was addressed through equity strategies to provide girls and boys with opportunities to play at the same centers. However, as I outline below, such efforts worked to promote a male-centered education for all students, placing girls at a disadvantage before they even entered the preschool classroom.

\section{Teachers' Beliefs in Equal Education and their Effects on Girls' Play Experiences}

My discussions with Sara, Hannah, Megan, and Laurie revealed a common belief that the play environment allowed for equal opportunities for all children. When Laurie and I discussed how children make use of the different centers, she asserted, "I think it's just equally." Hannah extended this sentiment and explained that "all centers are open to boys and girls." It seemed to me that these beliefs came about because there were no perceived restrictions in the play environment. While there were indeed no overt restrictions on who could play at the different centers, my fieldnotes show that there was an unequal mix of girls and boys consistently-typically a three to one 
ratio, at both the blocks, where boys outnumbered girls, and kitchen centers where the reverse was true. This observation suggests that the play environment may not necessarily allow for equal opportunities for girls and boys to discover "various trades and occupations" and that girls and boys are then not engaging with the same knowledges and skills. As Elizabeth Wood (2009) has pointed out, "Different play activities [and objects] create different 'affordances' for learning” (35).

While developmental objectives such as socializing, sharing, and turn taking, for instance, were promoted across the centers, the materials made available at each of the centers typically supported different targeted skills. The blocks center in each of the classrooms, for instance, was set up for children to practice their mathematical skills through sorting and counting activities. These centers also had construction tools and toys representing emergency services such as police and fire stations. At this center, the children tended to practice building structures and they explored first responder roles. Since the kitchen center was set up with different materials such as sets of cooking and baking utensils, home furniture, and dolls, children tended to practice housekeeping and child-rearing tasks and they also explored family roles in their play.

\section{Gender Separation during Classroom Play}

Research shows that through early socialization in the family, the media, the nursery, and in peer groups, children begin to define themselves as girl or boy as young as toddlerhood (Bussey and Bandura 1999; Freeman 2007). This helps to explain why children typically play separately in the classroom. According to Becky Francis, taking up gender traits is integral to the identity construction of young children and in their presenting themselves as socially competent beings. This means that children engage in processes of "gender category maintenance work" (1998: 10) in which they take up visual signs of their gender, such as the toys with which they play, to actively position themselves within the gender binary and maintain the categories of girl and boy as oppositional. As William Corsaro notes, "Gender-role expectations are not simply inculcated into children by adults; rather, they are socially constructed by children" (2012: 494).

Because certain centers are marked as feminine and others as masculine, many children play in spaces and with toys that seem socially acceptable for their sex and gender since they "find pleasure in 'getting it right' and 'being normal'” (MacNaughton 2006: 131). Since women are perceived to hold power in the domestic sphere and in mothering activities in our society, 
domestic play and taking on nurturing roles is often desired by young girls (Blaise 2005; Davies 1989). Bronwyn Davies (1989) notes that girls may feel safe, powerful, and in control in spaces like the kitchen center. Girls may then also play in these spaces to avoid being dominated by boys at the other centers, particularly since boys tend to dominate the blocks center as well as other spaces of the play and school environment (Bhana 2006; Thorne 1993).

Mindy Blaise (2005) makes the point that while children are aware of, and draw on, dominant gender discourses in their play, they also resist such discourses and cross gender boundaries. Therefore, while the girls in this study were found predominantly playing at the kitchen center, it was not uncommon for a girl to play at the blocks center. However, the girls were often unable to use the blocks center to its full potential and often took on subordinate roles at this center. Since the blocks center is considered a masculine space (Blaise 2005; MacNaughton 2000), the boys typically dominated this center and girls who entered it had little input on the play that unfolded. As Glenda MacNaughton explains, "Many boys position themselves within traditional ways of being male [and want] to control girls' access to block play and the nature of girls' involvement in the area" (2000: 120). One teacher in MacNaughton's study asks, "If boys and girls are playing together, what is the power structure? They can be playing together and it can be quite successful play, but where is the power, where is the control?" (2000: 15).

\section{Democratic Equality and the Effects on Girls' Education in Preschool}

In the liberal tradition, equality refers to the notion that all students are to be treated equally and must have the same opportunities regardless of differences between them or disadvantages that certain students may face (Jencks 2007). In this view, social categories of identities, like gender, that may work to subordinate some students in certain contexts while privileging others are not considered to be potential barriers. As Neil Thompson puts it, there is a "tendency to interpret the term 'equality' too literally" (2016: 12). He explains that while from a mathematical standpoint equality means sameness, when we are addressing discrimination the notion of equality should not promote sameness but difference of equal worth. Indeed, Noddings argues that in liberal understandings of equality, "[it] comes to mean participation in whatever that is, even if it is participation in name only" (2005: 41). As can be seen, the teachers in my study seemed to draw on a 
liberal concept of equality. Therefore, because there were no overt restrictions to any of the centers, they believed that girls and boys were able, at least theoretically, to access the centers available in the play environment equally. Hannah stated, "I have been able to see that girls enjoy playing with blocks." Megan agreed that "girls do like playing with the construction blocks." While girls may indeed enjoy playing at the blocks center we need to ask whether they could necessarily use this center to its full potential and benefit from the educational affordances it offers.

A play scenario that took place in Sara's classroom—one that was common to all four classrooms -illustrates how liberal notions of equality can work to mask gender power in children's play. One morning in Sara's classroom I spent some time at the blocks center with Matt, Ryan, Josh, and Beth. ${ }^{3}$ The three boys built a large castle together in the middle of the carpet, while Beth sat by herself at its edge. Using a small pile of blocks, she built what she described to me as bubbles. When the boys ran out of blocks for their castle, Ryan quickly turned to Beth and grabbed the blocks from her hands. Beth became upset and exclaimed, "No!" but the boys continued to take her blocks. Matt explained to Beth that they needed all the blocks they could get to build their big castle. Beth struggled with the boys for a short time and then gave up her blocks and went to play at the kitchen center. Illustrating Noddings's (2005) point about the relationship between participation and equality, Beth was present in the blocks center but she did not participate in the same way that the boys did. She could not carry out her own task effectively because she was left with no blocks and she was not invited to build the castle with the boys. As noted in other studies (Blaise 2005; MacNaughton 2000), some girls may consider playing at the blocks center as being too risky, forcing them to play in other areas of the play environment.

Liberal notions of equality are intimately intertwined with notions of free choice, which also underpin child-centered approaches dominant in early childhood education. In terms of a child-centered education, children "are viewed as active learners who require freedom from adult authority to explore ideas independently and make sense of their world" (Ryan 2005: 99). Within this framework, the concept of play is deeply embedded in notions of free choice. However, as Gaile Sloan Cannella (1997) argues, choice within a child-centered framework is an illusion since adults control the choices children have through the types of materials and activities they make available. Importantly, child-centered approaches assume equal agency among children in engaging with these materials and activities and do not consider the effects of social structures on children's choices. Sharon Ryan explains, 
The conceptions of power and agency on which child-centered approaches are based do not adequately address the complex ways classroom social relations are embedded and interconnected to other social meanings and practices... [such as] the kinds of gendered power relations young children enact and undergo when they are given opportunities to make choices and engage in play 'free' from adult authority. (2005: 100)

Discourses of free choice can thus work to mask the gender power children exercise to regulate the play environment. Given that the boys dominated the blocks center, Beth was forced to "choose" another center. She gravitated towards the kitchen center, which is associated with femininity and thus an acceptable and safe space in which girls can play. Therefore, as Davies (1991) might argue, while children do make choices during play, these may be, more often than not, forced choices since gender works to govern where a child can play.

\section{The Enduring Influence of Historical Philosophies of Education on Conceptions of Equality}

It seemed to me that the teachers did not perceive gender separated play to be an effect of unequal gender power relations, but rather a function of girls' and boys' assumed natural preference for playing at particular centers. Megan stated, "The girls love the kitchen center. They are always there." Hannah elaborated, "When it comes to the kitchen, [the girls] really take their roles seriously." Such gendered assumptions in education is highlighted throughout Rousseau's philosophy of education, which continues to influence Western education. In his Émile, ou De l'éducation [Emile, or On Education] ([1762] 2009), Rousseau has Émile, a young boy who grows up learning through inquiry in nature develop into an autonomous, reasonable man. Sophie, Émile's wife-to-be receives, instead, an education that prepares her to be an obedient wife and develop the capacity for care, nurturance, child rearing, decorating, and running a household. According to Rousseau, "It has been shown that men and women are essentially different in character and temperament, it follows that they ought not to have the same education" ([1762] 2009: 236). In his view, as we can see, differentiated learning based on gender is not considered unequal education.

The four teachers in my study also relied on biological determinism to explain differences in girls' and boys' play choices. When she was discussing a picture of boys playing at the kitchen center, Hannah explained, "[They were not] really using it to its advantage like girls would. I think it comes 
more naturally for girls." Sara shared a similar understanding of gender as rooted in biology. She said, "Girls from a very young age they're more into sitting. It's how I think genetically we are." While Megan and Laurie also relied on biological determinism, in other instances they also drew on sexrole socialization theories. Megan asked, "They develop [these interests] ... the [girls] that are princess lovers ... . Is that all they've been shown at home?" Similarly, Laurie believed that TV shows influence children's play preferences. She claimed, "Boys will be building towers or bridges things like that-manly things that are seen on TV to be ... manly things." Sex-role socialization theories like biological determinism assume that children are unknowing of the complexities of gender and passive in the construction of their gender identities and that an inherent and natural difference exists between the sexes working to naturalize the gender binary (MacNaughton 2000; B. Martin 2011).

While gender separated play was perceived as natural and reflective of children's interests, the teachers did carry out various strategies to close the gender gap. During my visits, I noticed that the spaces of a center were sometimes altered. Changing the configuration of a center is a common practice in early childhood education to respond to children's interests. However, doing so worked against gender equality. For instance, in an effort to encourage boys to play at the kitchen center, the space was often altered so that it was more appealing to boys' perceived interests. One morning in Laurie's classroom the blocks center had exceeded its capacity of four children in that four boys and one girl were building various structures and towers. Laurie tried to encourage some of these children to play at the kitchen center, at which only one student, Emma, was playing. She approached Melanie, the only girl in the blocks center, who was building a tower and said, "Why don't you make me some breakfast [in the kitchen]?" Melanie shook her head indicating that she did not want to change center. Laurie turned to Paul and said, "Paul, why don't we go in the kitchen and you can open up a restaurant!" Paul agreed and as he entered the kitchen center he quickly took over as chef, interrupting Emma's doll play.

Despite Laurie's good intention to ensure that the centers are not overloaded and that children are making equal use of the different centers, her proposal to Melanie and Paul worked to reinforce the gender binary in its reflecting the belief that girls and boys naturally have different interests. Melanie was encouraged to play at the kitchen without any changes having been made to the space. She was expected to use the kitchen center as a kitchen and engage in the domestic task of preparing breakfast. Paul, how- 
ever, was not expected to carry out the same tasks as Melanie at the kitchen center nor was he expected to join Emma's doll play, both activities that are typically associated with femininity. What is more, the kitchen center was transformed into a restaurant for Paul and he took on the role of chef, a prestigious occupation that is valued in society and yields a higher salary than the unpaid labor of cooking breakfast in the private sphere, the role Melanie was expected to carry out in her play. While striving towards equal education should not mean treating all children the same, as Thompson (2016) points out, the differences that are supported in this example do not seem to be of equal worth. Therefore, we do need to ask if the equity strategies that are employed necessarily ensure that girls and boys are receiving the same education in preschool.

\section{Perpetuating a Male-Centered Education through Equitable Practice}

Despite the gendered assumptions expressed by the teachers, it was not uncommon for equity strategies - the differential treatment of girls and boys to ensure equal education - to be carried out in these four classrooms. The notion that girls and boys should indeed learn the same knowledges and skills is not new. Here, we see the continued influence of Plato's philosophy of education on teacher practice. In the Republic (c. 380 BCE) Plato argues, "But if the difference consists only in women bearing and men begetting children, this does not amount to a proof that a woman differs from a man in respect of the sort of education she should receive" (cited in Agonito 1977: 29-30). Contrary to Rousseau then, Plato believed that women can take on the same pursuits as men and should receive the same education. Such a notion of equal education was also evident throughout my visits. For instance, during one visit Megan and I discussed how she encourages more girls to play at the blocks center. She explained, "If I'm taking three or four of the block [bins] out ... there's the ones with the little pink and the blue and the green ... the little pastel ones [geared towards the girls]." To mirror the linking blocks that boys usually integrate in their block play, Megan also includes snap-together jewelry toys in the blocks center in order to entice girls to play at this center. As seen with Paul in Laurie's classroom, Megan alters the space to encourage girls to play at the blocks center.

Importantly, the content to be learned at the blocks center was not altered. When they played at this center, the girls were expected to learn the same knowledges and skills as the boys, contrary to the gender expectations found at the kitchen center, where boys, like Paul, were not expected to prac- 
tice housekeeping in their play, nor were they expected to engage with nurturing capacities. Such gender perceptions and practices in early childhood education reflect and produce our society's inherent devaluation of the knowledges and capacities that are associated with femininity.

Indeed, J.R. Martin (1994) challenges the education philosophies of Rousseau and Plato. She argues that the ideal for education presented by these philosophers is male-centered. According to her, the social order is divided into two parts - the productive and reproductive processes of society. The former include cultural, political, social, military, and economic activities while the latter include childcare and rearing, activities related to maintaining the household, tending to the sick, and taking care of family needs. This division, she explains, is accompanied by a separation of the genders: women are associated with the reproductive and men with the productive processes of society. Importantly, it is the latter that hold power and prestige and, as J.R. Martin argues, the curriculum privileges these productive processes and this leads to the sexual division of labor.

While Plato advocates that men and women should receive the same education, J.R. Martin $(1994,1985)$ highlights that the education to be received is only for the productive processes of society which are promoted, in part, by activities like block play. The reproductive processes fall outside of formal education since they are not considered essential for the Just State. Although Rousseau includes these reproductive processes in Sophie's education, Émile is not expected to learn what Sophie has been taught such as child rearing, tending to family needs, looking after those who are sick, and running a household. Yet, in book V of Émile, ou De l'éducation, Rousseau has Émile teaching Sophie everything he knows, "philosophy, physics, mathematics, history, everything in fact” (cited in Cahn 2009: 241), all of which belong to the productive processes of society. Importantly, As J.R. Martin (1985) points out, the reproductive processes Sophie learns are not considered essential for citizenship or public life thereby resulting in her taking on a secondary role in society. In both Plato's and Rousseau's ideal for education the productive and reproductive processes of society do not hold equal worth. As shown in the play examples above, the learning of so-called male knowledges and skills continues to be privileged in education.

Equity strategies thus do not necessarily ensure that girls and boys receive the same education if what is taught in the explicit curriculum is male-centered. That is not to suggest that teaching activities and supporting capacities that are traditionally thought of as feminine should become the norm in education or that all such activities are necessarily valuable. Instead, 
as J.R. Martin explains, the point is "that when the activities and experiences traditionally associated with women are excluded from the educational realm and when that realm is defined in terms of male activities and experiences, then these become the educational norms for all human beings" (1982: 146). Consequently, children may be led to believe that only what are thought of as male knowledges and trades and occupations are valuable in society and thus worth learning and striving toward.

\section{Addressing Gender Inequality in Early Childhood Education}

When she discussed the challenges of addressing the gender gap in children's play, Laurie pointed to an important observation on which the other teachers had also remarked. She noted, "If [the boys] don't get the blocks center, then they just don't know what to do. They'll go to the kitchen center and they'll just sit there." Laurie highlights an important predicament that teachers face. Teachers are mandated to implement a child-centered framework and support their students' interests with minimal involvement. Should teachers then intervene during play to ensure an equal education between girls and boys, even if intervening may be perceived as bad practice? Should teachers not aim to ensure that all children learn the skills necessary to be successful in school and public life, even if it does privilege the productive processes of society? Noddings (2005) argues that accepting a liberal education reproduces a society in which only females are expected to care for and emotionally support others, thus ensuring perpetual inequality for girls and women.

In this section, I focus on the importance of challenging the gender binary and offer ways in which gender inequality in early childhood education may be addressed. As Bronwyn Davies and Chas Banks (1992) point out, discourses of equal opportunity do not actually challenge the social construction of gender nor the naturalization of the gender binary. Instead, equal opportunities discourses often work to ensure that both genders are given the opportunity to perform the same activities and, I would argue, they lead almost exclusively to providing girls with opportunities to perform so-called male activities and less so the other way around. However, this continues to reinforce the gender dualism because it assumes that girls and boys are naturally different and necessarily interested in different activities. In order to effectively address the unequal education of girls and boys, J.R. Martin points out that "we need a conception that does not fall into the trap of assigning males and females to the different processes of society, yet 
does not make the mistake of ignoring one kind of process altogether" (1994: 81). Here, I turn to Noddings's concept of an ethics of care to explore how we might address the issues J.R. Martin has raised.

Noddings argues that the liberal curriculum is not an adequate ideal for education since it promotes a narrow set of human capacities and the content is not one that all students need. Instead, she contends that developing caring relations is a much more important ideal for education since all human beings desire to be cared for. She explains, "Just as we now think it is important for girls as well as boys to have mathematical experience, so we should want both boys and girls to have experience in caring" (2005: 24). Care for Noddings, however, is not simply an individual characteristic, but "a way of being in relation" (17) and should be integrated into all areas of the curriculum. The aim of education should be to support attitudes and skills that are necessary for sustaining caring relations and for nurturing students' growth into loving and lovable people. She explains, "All students should be engaged in a general education that guides them in caring for the self, intimate others, global others, plants, animals, and the environment, the human-made world, and ideas" (173). In the context of early childhood education, integrating an ethics of care is not necessarily about changing the landscape of the play environment (like, for example, removing or integrating centers) or changing the types of activities children carry out at the centers. Instead, change may reside in reimagining what else can be learned at the existing centers. It requires refocusing the pedagogical gaze so as to include fostering caring relations and capacities at all the centers for all children. For instance, as boys learn to count and build at the blocks center, they may also be encouraged to care for the objects, the space, and, importantly, to respect and include their female peers and their ideas. While children may exhibit caring capacities at the kitchen center as they tend to a baby or model caring relations between parents as they play house, such skills can also be supported in other spaces, such as the blocks center, where children can practice carrying out a respectful dialogue as they build towers together.

How will an ethics of care help teachers strive toward gender equality in the preschool classroom? Integrating a care ethics across the curriculum may help dissolve the misconception that care is important only in certain spaces and should be carried out only by certain people (girls and women). Integrating care throughout the curriculum may work to break down the rigid gender associations with particular centers, capacities, and knowledges and thus challenge the gender binary. Encouraging care behaviors in the blocks center, a typically hegemonic masculine space, may help communi- 
cate to children that caring is a capacity that boys are also capable of expressing and for which they are also responsible. This would work to dissociate reproductive processes of society from those thought to be the exclusively feminine capacities that are to be carried out only by girls and women. Doing so may then help us to reconsider our understanding of the genders as opposite ways of being. As MacNaughton, among many other feminists, makes clear, "The struggle for women's equality must contest the binary opposition of gender" (2000: 150).

Davies (1989) stresses the importance of integrating new discourses into the curriculum and teaching practices, particularly ones that work to situate children as neither female nor male, but as human beings. Integrating an ethics of care into the curriculum may help to see caring relations and capacities as not belonging exclusively to girls and, in so doing, may allow alternative masculinities to exist and be valued in the classroom. As others have argued, radical change is needed in our understanding of gender if gender equality is to prevail in schools (Blaise 2005; Davies 1989). It is only when all children are responsible for learning both the reproductive and productive processes of society and when both processes are addressed in the explicit curriculum and in non-dichotomous ways can we begin to conceive of an equal education in the preschool classroom.

\section{Conclusion}

We can see that, despite a common perception among the teachers that equal education prevails in their classrooms, girls and boys continue to receive an unequal education in preschool. From a young age then, girls and boys may be taught different knowledges and skills and are thereby inculcated into unequal social roles. Equality discourses, as Davies and Banks (1992) argue, do not challenge the gender binary upon which inequality relies. As I have shown, advocating for girls' equal education usually comes to mean that girls must meet the male standard in school; girls are to learn the productive processes of society in the explicit curriculum, while implicitly learning to carry out the reproductive processes of society. Consequently, the broader unequal (gendered) power structures that underpin Western education remain unchallenged.

I use Noddings's concept of an ethics of care in education to propose a way to stop seeing caring and nurturing capacities as belonging exclusively to girls and women. Introducing an ethics of care into the curriculum will 
convey to children that these are important capacities for which all people can and should be responsible. In this way, we can challenge normative gender relations and re-conceptualize the concept of equality in education by problematizing education's underlying values and ideologies. However, several questions remain for future research. What challenges may teachers face when developing an ethics of care in a climate that devalues such capacities? How might teachers' gender perceptions influence the implementation of an ethics of care in their classrooms and how might families and the community affect the implementation of this in early childhood education? While such questions have yet to be explored, problematizing the current state of early childhood education is the necessary first step in working towards an equal education for all children.

\section{Acknowledgments}

I would like to express my gratitude to Claudia Mitchell for her guidance throughout my master's study, on which this article is based. I thank Lauren Bialystok, the reviewers of my article, and Ann Smith for their helpful comments on an earlier version of this manuscript.

$\cos$

Jessica Prioletta is a PhD student at the Ontario Institute for Studies in Education, University of Toronto, in the Social Justice Education and Women and Gender Studies collaborative program. Her research interests focus on early childhood education and gender, particularly in the context of play. The study from which this article arose was awarded the Social Sciences and Humanities Research Council of Canada Graduate Scholarship for Masters. E-mail: jessica.prioletta@mail.utoronto.ca

\section{Notes}

1. While we no longer think of gender as being a binary, I use this formulation since the objective of this article is to explore how schools work to produce and maintain such dominant constructions of gender.

2. Self-selected pseudonyms have been used for all teacher participants to ensure their anonymity.

3. The names of the children are all pseudonyms. 


\section{References}

Ackerly, Brooke A, and Jacqui True. 2010. Doing Feminist Research in Political and Social Science. Basingstoke, UK: Palgrave Macmillan.

Agonito, Rosemary. 1977. History of Ideas on Woman: A Source Book. New York: Perigee Books.

Bhana, Deevia. 2006. "'Doing Power': Confronting Violent Masculinities in Primary Schools." In Combating Gender Violence in and around Schools, ed. Fiona Leach and Claudia Mitchell, 171-180. Stoke-on-Trent, UK: Trentham Books. Blaise, Mindy. 2005. Playing it Straight: Uncovering Gender Discourses in the Early Childhood Classroom. New York: Routledge Taylor \& Francis Group.

Bussey, Kay, and Albert Bandura. 1999. "Social Cognitive Theory of Gender Development and Differentiation." Psychological Review 106: 676-713. Cannella, Gaile Sloan. 1997. Deconstructing Early Childhood Education: Social Justice and Revolution. New York: Peter Lang Publishing.

Cherney, Isabelle D., and Jessica Dempsey. 2010. "Young Children's Classification, Stereotyping and Play Behaviour for Gender Neutral and Ambiguous Toys." Educational Psychology 30 (6): 651-669.

Corsaro, William A. 2012. "Interpretive Reproduction in Children's Play." American Journal of Play 4 (4): 488-504.

Davies, Bronwyn. 1989. Frogs and Snails and Feminist Tales: Preschool Children and Gender. Sydney: Allen \& Unwin Pty Ltd.

Davies, Bronwyn. 1991. "The Concept of Agency: A Feminist Poststructuralist Analysis." Social Analysis 30: 42-53.

Davies, Bronwyn, and Chas Banks. 1992. "The Gender Trap: A FeministPoststructuralist Analysis of Primary-School Children's Talk about Gender." Junior Curriculum Studies 24: 11-25.

Francis, Becky. 1998. Power Plays: Primary School Children's Constructions of Gender, Power, and Adult Work. Stoke-on-Trent, UK: Trentham Books.

Freeman, Nancy K. 2007. "Preschoolers' Perceptions of Gender Appropriate Toys and their Parents' Beliefs about Genderized Behaviors: Miscommunication, Mixed Messages, or Hidden Truths?" Early Childhood Education Journal 34 (5): 357-366.

Jencks, Christopher. 2007. "Whom Must We Treat Equally for Educational Opportunity to be Equal?” In Philosophy of Education: An Anthology, ed. Randall Curren, 243-253. Malden, UK: Blackwell Publishing Ltd.

Jones, Liz, and Bridget Somekh. 2005. "Observation." In Research Methods in the Social Sciences, ed. Bridget Somekh and Cathy Lewin, 138-145. London: SAGE Publications Ltd.

MacNaughton, Glenda. 2000. Rethinking Gender in Early Childhood Education. London: Paul Champlain Publishing Ltd. 
MacNaughton, Glenda. 2006. "Constructing Gender in Early-Years Education." In The SAGE Handbook of Gender and Education, ed. Christine Skelton, Becky Francis, and Lisa Smulyan, 127-138. London: SAGE Publications Ltd. Martin, Barbra. 2011. Children at Play: Learning Gender in the Early Years. Staffordshire, VA: Trentham Books.

Martin, Jane Roland. 1982. "Excluding Women from the Educational Realm." Harvard Educational Review 52 (2): 133-148.

Martin, Jane Roland. 1985. Reclaiming a Conversation: The Ideal of the Educated Woman. New Haven: Yale University Press.

Martin, Jane Roland. 1994. Changing the Educational Landscape: Philosophy, Women, and Curriculum. New York: Routledge.

Ministère de l'Éducation du Loisir et du Sport [Ministry of Education, Sports and Leisure]. 2001. Québec Education Program: Preschool and Elementary Education. http://www1.mels.gouv.qc.ca/sections/programmeFormation/ primaire/pdf/educprg2001bw/educprg2001bw.pdf (accessed 12 April 2016).

Nelson, Anders. 2011. "Gendered Toy Play as Mediated Action." Psychological Science and Education 2: 71-77.

Noddings, Nel. 2005. The Challenge to Care in Schools: An Alternative Approach to Education. (2nd ed.) New York: Teachers College Press.

Punch, Keith F. 2009. Introduction to Research Methods in Education. London: SAGE Publications Ltd.

Rousseau, Jean-Jacques. [1762] 2009. "Émile." In Philosophy of Education: The Essential Texts, ed. Steven M. Cahn, 205-245. London: Routledge.

Ryan, Sharon. 2005. "Freedom to Choose: Examining Children's Experiences in Choice Time." In Critical Issues in Early Childhood Education, ed. Nicola Yelland, 99-114. Berkshire UK: Open University Press.

Thompson, Neil. 2016. Anti-Discrimination Practice: Equality, Diversity and Social Justice. (6th ed.) London: Palgrave Macmillan.

Thorne, Barrie. 1993. Gender Play: Girls and Boys in School. New Brunswick, NJ: Rutgers University Press.

Wood, Elizabeth. 2009. "Developing a Pedagogy of Play." In Early Childhood Education: Society and Culture (2nd ed.), ed. Angela Anning, Joy Cullen and Marilyn Fleer, 27-38. London: SAGE Publications Ltd. 